\title{
PARTISIPASI PEMILIH MASYARAKAT PADA PEMILIHAN WALIKOTA DAN WAKIL WALIKOTA TANGERANG SELATAN TAHUN 2020
}

\author{
Toni Anwar Mahmud \\ Universitas Banten Jaya \\ Serang, Indonesia \\ toniam@unbaja.ac.id
}

\begin{abstract}
Stipulation of Law of the Republic of Indonesia Number 6 of 2020 concerning Stipulation of Government Regulations in Lieu of Law Number 2 of 2020 concerning Third Amendments to Law Number 1 of 2015 concerning Stipulation of Government Regulations in Lieu of Law Number 1 of 2014 concerning Election of Governors, Regents, and the Mayor Becomes Law Becomes Law on August 11, 2020, has stipulated that the simultaneous regional elections in 2020 will be held on December 9, 2020, even though the Covid-19 pandemic is ongoing and there are significant additional positive cases. This research uses a qualitative approach and uses literature study. The results of this study show that there is an increase in voter participation in the 2020 elections for South Tangerang City compared to the 2020 elections, which amounted to 3.06\%. The total voter turnout for the 2020 elections was 594,711 voters consisting of 575,725 valid votes, 18,986 invalid votes. The people of South Tangerang City who exercised their voting rights were only $60.93 \%$ of the 976,019 DPT stipulated by the South Tangerang City KPU or 381,308 (39.07\%) South Tangerang City voters did not exercise their voting rights. Meanwhile, in the 2015 regional elections, voter participation was $57.87 \%$ with a total number of voters of 920,115 people and users of voting rights as many as 533,444 people.
\end{abstract}

Keywords: Role of Parents, Forming Character, Globalization Era

\section{PENDAHULUAN}

Pemerintah menetapkan UndangUndang Republik Indonesia Nomor 6 Tahun 2020 Tentang Penetapan Peraturan Pemerintah Pengganti Undang-Undang Nomor 2 Tahun 2020 Tentang Perubahan Ketiga Atas Undang-Undang Nomor 1 Tahun 2015 Tentang Penetapan Peraturan Pemerintah Pengganti Undang-Undang Nomor 1 Tahun 2014 Tentang Pemilihan Gubernur, Bupati, dan Walikota Menjadi Undang-Undang Menjadi Undang-Undang pada tanggal 11 Agustus 2020. Dalam undang-undang tersebut dinyatakan bahwa dalam kondisi pandemi Corona Virus
Disease 2019 (Covid-19) pemilihan gubernur dan wakil gubernur, bupati dan wakil bupati, serta walikota dan wakil walikota tetap dapat berlangsung secara demokratis dan berkualitas serta untuk menjaga stabilitas politik dalam negeri.

Pada pelaksanaan pilkada serentak tahun 2020 dilaksanakan oleh 270 daerah di Indonesia yang terdiri dari Pemilihan gubernur dan wakil gubernur (9 provinsi), Pemilihan Wali Kota dan Wakil Wali Kota (37 kota) dan Pemilihan Bupati dan Wakil Bupati (224 kabupaten). 
Menurut Tim FH Universitas Jambi Pilkada, dimasa pandemi Covid-19 ini juga dikhawatirkannya menurunnya minat Pemilih dari masyarakat, dan Ini jelas bertentangan dengan tujuan pelaksaan Pilkada itu sendiri karena dalam pelaksanaan pilkada ini sendiri selain mencari Pemimpin bagi masyarakat, dibutuhkan suara dan peran serta masyarakat dalam pemilihan itu sendiri. Kalau Pilkada diselenggarakan ditengah pandemi covid-19 kemungkinan masyarakat/pemilu akan enggan untuk mendatangi TPS karena rasa kekhawatiran terhadap virus covid-19 itu sendiri, dan takutkan adanya kecurangan dalam perhitungan atau perolehan suara. Di karenakan banyaknya kekhawatiran Masyarakat yang mengakibatkan Para Pemilih kekurangan minat untuk datang ketempat pemilihan, hal ini dapat menimbulkan kecurangan dalam prolehan suara dimana ditakutkan akan meningkatnya masyarakat yang memilih golput sehingga di khawatirkan dapat disalah gunakan hak suara masyarakat yang tidak menggunakan hak suaranya, di tambah lagi Covid-19 ini menyerang berbagai kalangan tanpa terkecuali.

Sementara Mokhammad Samsul Arif, 2020 mengatakan, Meskipun tidak dapat digeneralisir, tingkat partisipasi pemilih di beberapa daerah umunya masih sangat rendah. Dari hasil laporan Jaringan
Pendidikan Pemilih untuk Rakyat (JPPR) dapat diketahui jika tingkat partisipasi pemilih pada Pilkada yang dilaksanakan di 229 daerah, dari total 264 daerah yang melaksanakan pemungutan suara pada 9 Desember 2015 rata-rata hanya mencapai 69 persen (jpnn.com).

Rinciannya, 34 daerah tingkat partisipasinya dibawah 60 persen. Kemudian 84 daerah berkisar 60-70 persen. Tingkat partisipasi di 88 daerah berkisar 70-80 persen dan 23 daerah di atas 80 persen (jpnn.com, 2015).

Tabel 1. Sepuluh Daerah Dengan Angka Partisipasi Terendah Pilkada 2015

\begin{tabular}{|l|l|l|}
\hline No & $\begin{array}{c}\text { KABUPATEN/ } \\
\text { KOTA }\end{array}$ & $\begin{array}{c}\text { ANGKA } \\
\text { PARTISIPASI } \\
(\%)\end{array}$ \\
\hline 1 & Medan & 27 \\
\hline 2 & Batam & 50 \\
\hline 3 & Serang & 51 \\
\hline 4 & Waringin Timur & 52 \\
\hline 5 & Jember & 52 \\
\hline 6 & Tuban & 52 \\
\hline 7 & Surabaya & 52 \\
\hline 8 & Karimun & 54 \\
\hline 9 & $\begin{array}{l}\text { Padang } \\
\text { Pariaman }\end{array}$ & 55 \\
\hline 10 & Agam & 55 \\
\hline
\end{tabular}

Sumber : jppn.com, 2015

Chaniago, dalam Arif, 2020, Masih banyaknya daerah yang tingkat partisipasinya rendah disebabkan karena sosialisasi penyelenggaraan pemilu yang kurang optimal. Berikutnya, Pilkada serentak tidak terlalu semarak apabila dibandingkan dengan Pilkada-Pilkada 
sebelumnya dikarenakan aturan KPU yang memperketat pengunaan alat peraga dalam rangka menghemat biaya Pemilu.

Meskipun pada Pilkada Serentak gelombang dua mencatatkan peningkatan angka kehadiran pemilih datang ke TPS pada hari pemungutan suara, namun selang satu tahun kemudian angka partisipasi alih-alih meningkat justru pada Pilkada Serentak 2018 terjadi penurunan sebesar satu persen.

$$
\text { Partisipasi pemilih yang }
$$
menggunakan hak pilih (voters turnout) merupakan salah satu parameter keberhasilan sebuah pemilihan, entah itu Pemilu maupun Pilkada. Pada saat sistem pembagian kekuasaan kita telah bertransformasi dari sentralistis ke desentralistis, maka Kepala Daerah yang dipilih langsung idealnya memiliki legitimasi cukup kuat (Riewanto dalam Arif, 2020).

Provinsi Banten sendiri melaksanakan pilkada serentak di 4 (empat) Kabupaten/Kota yaitu Kabupaten Pandeglang, Kabupaten Serang, Kota Cilegon dan Kota Serang. Pada penelitian kali ini penulis hanya membatasi pada partisipasi pemilih pilkada Kota Tangerang Selatan di masa pandemi Coivd-19. Mengingat plkada kota Tangerang Selatan diikuti oleh kandidat calon walikota dan wakil walikota yang beririsan dengan elit politik di pemerintah pusat.
Kandidat tersebut yaitu calon wali kota Muhamad dan wakil walikota Rahayu Saraswati Djojohadikusumo (Sara) yang diusung oleh Partai Demokrasi Indonesia Perjuangan (PDIP), Partai Gerakan Indonesia Raya (Gerindra), Partai Solidaritas Indonesia (PSI), Partai Amanat Nasional (PAN) dan Partai Hati Nurani Rakyat (Hanura).

Rahayu Saraswati Djojohadikusumo merupakan anak dari Hashim Djojohadikusumo sekaligus merupakan keponakan dari Menteri Pertahanan dan Keamanan, Prabowo Subianto. Selanjutnya, pasangan Siti Nur Azizah dan Ruhamaben sebagai calon walikota dan wakil walikota Tangerang Selatan. Pasangan tersebut diusung oleh Partai Keadilan Sejahtera (PKS), Partai Demokrat, dan Partai Kebangkitan Bangsa (PKB). Siti Nur Azizah adalah anak dari Wakil Presiden Republik Indonesia Ke-13 yaitu K.H. Ma'ruf Amin.

Pasangan berikutnya adalah Pasangan nomor urut 3 adalah Benyamin Davnie-Pilar Saga Ichsan yang diusung oleh Partai Golongan Karya (Golkar) ditambah tiga partai yang tidak memiliki kursi di DPRD Tangerang Selatan turut serta mendukung yakni Partai Persatuan Pembangunan (PPP), Partai Bulan Bintang (PBB), dan Partai Gelombang Rakyat Indonesia (Gelora Indonesia). 
Benyamin Davnie sebagai Calon Walikota Tangerang Selatan, merupakan Wakil Walikota Tangerang Selatan dua periode yaitu periode 2010-2015 dan periode 2015-2020 dimana Benyamin mendampingi Wali Kota Tangerang Selatan dua periode, Airin Rachmi Diany. Ketiga kandidat tersebut bersaing dalam pilkada serentak 2020 di masa Pandemi Covid-19.

Pada pilkada kota Tangerang sebelumnya yaitu tahun 2015, partisipasi pemilih 57,87\% dengan jumlah pemilih sebanyak 920.115 orang dan Pengguna hak pilih sebanyak 533.444 orang (sumber: https://pilkada2015.kpu.go.id/tangselkota).

Dalam kondisi yang tidak terdapat pandemi Coivd-19 partisipasi pemulih tidak mencapai $60 \%$, sehingga dengan kondisi pandemi apakah jumlah partisipasi pemilih akan menjadi lebh turun atau ada faktor profil dari para calon walikota yang memiliki keterkaitan dengan dinasti pemerintah pusat akan meningkatkan partisipasi pemilih pada pilkada serentak di Kota Tangerang Selatan?

Serta apakah jaminan penyelenggara dalam hal ini KPU telah menerapkan Protokol kesehatan selama pengambilan suara di TPS dapat memberikan rasa aman bagi pemilih mengingat banyak aktifitas warga yang terhenti akibat penerapan PSBB, WFH dan sekolah online sehingga memungkinkan

\section{METODE PENELITIAN}

Pada penelitian kali ini, penulis menggunakan metode dengan pendekatan kualitatif, yaitu Menurut sugiyono (2016:6) metode penelitian diartikan sebagai cara ilmiah untuk mendapatkan data yang valid dengan tujuan dapat ditemukan, dikembangkan, dan dibuktikan suatu pengetahun tertentu sehingga pada gilirannya dapat digunakan untuk memahami, memecahkan dan mengantisipasi masalah dalam bidang pendidikan.

Berdasarkan pada uraian sebelumnya, metode yang digunakan dalam penelitian kali ini adalah metode penelitian deskriptif dengan pendekatan kualitatif.

Sumber data diperoleh melalui studi kepustakaan dari Peraturan-peraturan, keputusan-keputusan KPU, buku-buku, media cetak dan internet yang dapat digunakan dalam mengkaji partsipasi pemilih pada Pilkada serentak Kota Tangerang Selatan tahun 2020.

Adapun teknik pengumpulan data pada penelitian menggunakan teknik pengumpulan data dengan tinjauan pustaka. Studi kepustakaan merupakan langkah yang penting dimana setelah seseorang peneliti menetapkan topik penelitian, langkah selanjutnya adalah melakukan kajian teoritis dan referensi 
yang terkait dengan penelitian yang dilakukan. (Sugiyono, 2017:291).

\section{Patisipasi politik}

Partisipasi politik menurut Sitepu, dalam Primandha Sukma Nur Wardhani adalah suatu kegiatan dari warga negara baik secara langsung maupun tidak langsung (tidak sengaja) terkait dengan kebijakan-kebijakan pemerintah dapat dilakukan oleh indvidu-individu maupun kelompok secara spontan maupun dimobilisasi. Disisi lain juga merumuskan bahwa partisipasi politik adalah merupakan kegiatan-kegiatan yang dilakukan oleh individu maupun kelompok untuk ikutserta secara aktif dalam kehidupan politik yakni dengan memilih pimpinan negara baik secara langsung maupun tidak langsung.

Sementara menurut Idil Akbar, 2017 mengatakan bahwa partisipasi rakyat menjadi indikator cukup penting untuk menggambarkan bagaimana kesuksesan penyelenggaraan sebuah pemilihan. Meski, tinggi rendahnya partisipasi rakyat dalam pemilihan tak selalu berkorelasi secara linier dengan kualitas pemilihan itu sendiri. Kualitas yang lebih menyandarkan pada upaya untuk memberi pemahaman tentang pemilihan melalui pendidikan politik, sosialisasi dan komunikasi serta artikulasi dan agregasi merupakan bagian penting dari penyelenggaraan pemilihan yang berkualitas.
Dalam kesempatan ini penulis menyoroti bagaimana partisipasi masyarakat dalam melakukan partisipasi politik yang lebih sederhana yaitu dengan menggunakan hak pilihnya yaitu datang ke Tempat Pemungutan Suara (TPS) dan memilih salah satu pasangan calon walikota dan wakl walikota Tangerang Selatan.

Sejalan dengan pendapat Miriam Budiardjo, dalam Cucu Sutrisno (2017) Partisipasi Politik adalah kegiatan seseorang atau suatu kelompok orang untuk ikut secara aktif dalam suatu kehidupan politik, dengan jalan memilih pemimpin negara dan secara langsung atau tidak langsung memengaruhi kebijakan pemerintah.

$$
\text { Pilkada langsung sejatinya }
$$
merupakan jalan demokrasi dan amanat konstitusi Indonesia yang harus terselenggara secara demokratis. Pilkada yang demokratis dapat menjadi lambang sekaligus salah satu tolak ukur demokrasi modern di Indonesia apabila hasilnya menjadi cerminan partisipasi dan aspirasi masyarakat serta diselenggarakan dalam suasana keterbukaan dengan kebebasan berpendapat dan berserikat (Budiarjo, 2008: 461). Suatu Pemilu yang demokratis adalah yang memenuhi tiga prasyarat demokrasi yakni: 1) adanya kompetisi memperebutkan dan mempertahankan kekuasaan; 2) adanya partisipasi 
masyarakat, 3) adanya jaminan hak-hak sipil dan politik (Marijan, 2010: 83). Partisipasi masyarakat merupakan salah satu yang harus dihadirkan dalam pemilu karena apabila partisipasi masyarakat tidak atau kurang hadir maka pemilu yang dilaksanakan bukan Pemilu yang demokratis (Santoso, 2006: 12). Menurut Eko (2003: 307-309), Pemilu demokratis akan terwujud apabila kompetisi elite, partisipasi masyarakat maupun liberalisasi politik berupa jaminan hak-hak politik dilaksanakan secara demokratis yakni secara terbuka, bebas, jujur, adil, tanpa tekanan, tanpa intimidasi, dll. Pilkada sebagai bagian dari Pemilu juga harus dilaksanakan dengan hadirnya partisipasi politik warga negara. Artinya, partisipasi warga negara dalam Pilkada tidak boleh absen namun harus berkualitas karena akan menentukan demokratis atau tidaknya Pilkada yang dilaksanakan.

\section{PEMBAHASAN}

Kondisi pandemi Covid-19 tidak menyurutkan pemerintah pusat untuk menunda pelaksanaan pilkada serentak 2020. Meski sempat terjadi polemik tetapi hanya berujung pada penundaan pelaksanaan Pilkada yang semula dijadwalkan pada 23 September 2020 ditunda menjadi tanggal 9 Desember 2020.

Dari jumlah kasus positif, Sepanjang Mei 2020 jumlah kasus positif Covid-19 melonjak drastis. Terhitung sejak 1 sampai 31 Mei, jumlah kasus positif mencapai 16.355 orang. Angka tersebut meningkat dua kali lipat ketimbang April 2020. Pada kurun waktu 1 sampai 30 April, kasus positif virus corona sebanyak 8.590 kasus (https://www.cnnindonesia.com/nasional/2 0200601103545-20-508637/lonjakandrastis-kasus-corona-pada-mei-2020).

Pada pelaksanaan pilkada pemilihan walikota dan wakil walikota Tangerang Selatan yang dilaksanakan 9 Desember 2020. Jumlah Daftar Pemillih Tetap berdasarkan Keputusan Komisi Pemilihan Umum Kota Tangerang Selatan Nomor: 470/HK.03.1-Kpt/3674/KPU-

Kot/XII/2020 Tentang Penetapan Jumlah Pemilih Terdaftar Dalam Daftar Pemilih Tetap (DPT) pada Pemilihan Wali Kota Dan Wakil Wali Kota Tangerang Selatan Tahun 2020 ditetapkan sebanyak 976.019 pemilih.

Dalam pelaksanaan pilkada Kota Tangerang Selatan terlihat bahwa penerapan protokol kesehatan secara ketat dilaksanakan oleh Kelompok Penyelenggara Pemungutan Suara (KPPS) pada setiap Tempat Pemungutan Suara (TPS).

Ketua KPU Kota Tangerang Selatan Bambang Dwitoro di Tangerang, Rabu (9/12/2020), mengatakan masyarakat diharapkan bisa menggunakan hak pilihnya dengan datang ke TPS. 
KPU memastikan seluruh TPS sudah dilakukan pembersihan dengan penyemprotan disinfektan dan menyiapkan alat pelindung diri (APD) bagi petugas maupun pemilih.

Bambang juga mengatakan, "Terkait mekanisme pencoblosan di TPS pada masa pandemi ini sudah kita sampaikan kepada KPPS dan PPK melalui Bimtek beberapa waktu lalu agar selalu mengutamakan protokol kesehatan," (https://kabar24.bisnis.com/read/20201209 /15/1328375/pilkada-tangsel-2020sebanyak-979109-pemilih-mencoblos-hariini).

Sementara itu Wali Kota Tangerang Selatan (Tangsel) Airin Rachmi Diany mengklaim tempat pemungutan suara (TPS) Pilkada Serentak 2020 sudah mengikuti protokol kesehatan Covid-19. Hal itu dia sampaikan saat meninjau langsung TPS 30 di daerah Serpong Utara. "Dari pantauan yang kita lihat alhamdulillah sudah mengikuti prokes," kata Airin usai meninjau langsung di lokasi TPS tersebut, Rabu (9/12/2020). Airin menyaksikan, petugas Kelompok Penyelenggara Pemungutan Suara (KPPS) sudah menyediakan tempat cuci tangan, hand sanitizer, sarung tangan bagi pemilih. Bahkan, petugas juga sudah siap untuk mengecek suhu bagi pemilih yang akan memasuki lokasi TPS.
Airin juga mengatakan, Meskipun petugas KPPS sudah menyiapkan kebutuhan protokol kesehatan Covid-19, politikus Golkar itu tetap berharap agar para pemilih sudah mempersiapkan kebutuhan tersebut dari rumah sebelum berangkat ke TPS. (https://www.inews.id/news/megapolitan/a irin-klaim-semua-tps-pilkada-tangselpatuhi-protokol-kesehatan).

Selanjutnya pada pelaksanaan pilkada tersebut berdasarkan hasil dari perhitungan suara melalaui Keputusan Komisi Pemilihan Umum Kota Tangerang Selatan Nomor 470/Hk.03.1Kpt/3674/Kpu-Kot/ XII/2020 Tentang Penetapan Rekapitulasi Hasil Penghitungan Suara Pemilihan Wali Kota Dan Wakil Wali Kota Tangerang Selatan Tahun 2020, jumlah partisipasi pemilih sebanyak 594.711 pemilih yang terdiri dari suara sah 575.725 suara, jumlah suara tidak sah sebanyak 18.986 suara. Sehingga jika dilihat dari masyarakat Kota Tangerang Selatan yang menggunakan hak pilihnya hanya sebesar $60,93 \%$ dari 976.019 DPT yang ditetapkan KPU Kota Tangerang Selatan atau sebanyak 381.308 $(39,07 \%)$ pemilih Kota Tangerang Selatan tidak menggunakan hak pilihnya.

Dibandingkan dengan pilkada Kota Tangerang tahun 2015, partisipasi pemilih $57,87 \%$ dengan jumlah pemilih sebanyak 920.115 orang dan Pengguna hak pilih 
sebanyak 533.444 orang (sumber: https://pilkada2015.kpu.go.id/tangselkota). Sehingga terjadi kenaikan partisipasi pemilih dari tahun 2020 sebesar $3,06 \%$ dibandingkan dengan pilkada Kota Tangerang Selatan tahun 2015. Demikian juga dengan jumlah DPT pada Pilkada tahun 2020 bertambah sebesar 5,73\% atau sebanyak 55.904 pemilih. Dari data tersebut dapat dilihat bahwa kondisi Pandemi Covid-19 tidak menyurutkan masyarakat untuk menggunakan hak pilihnya dengan tetap datang ke TPS serta menerapkan protokol kesehatan yang telah ditetapkan oleh Komisi Pemilihan Umum melalui Peraturan Komisi Pemilihan Umum Republik Indonesia Nomor 13 Tahun 2020 Tentang Perubahan Kedua Atas Peraturan Komisi Pemilihan Umum Nomor 6 Tahun $2020 \quad$ Tentang Pelaksanaan Pemilihan Gubernur Dan Wakil Gubernur, Bupati Dan Wakil Bupati, Dan/Atau Wali Kota Dan Wakil Wali Kota Serentak Lanjutan Dalam Kondisi Bencana Nonalam Corona Virus Disease 2019 (Covid-19).

Dalam PKPU pasal 74 dinyatakan:

(1) Pemberian suara pada Pemilihan Serentak Lanjutan dilakukan dengan menerapkan protokol kesehatan pencegahan dan pengendalian Corona Virus Disease 2019 (COVID-19), dengan ketentuan sebagai berikut: a. Pemilih menggunakan sarung tangan sekali pakai untuk mencoblos dengan paku yang telah disediakan; dan b. anggota KPPS melakukan sterilisasi paku secara berkala dengan disinfektan.

(2) Pemilih yang telah selesai memberikan suara membuang sarung tangan sekali pakai pada tempat pembuangan yang telah disediakan di TPS.

(3) Pemilih yang telah memberikan suaranya sebagaimana dimaksud pada ayat (1) mendatangi anggota KPPS yang bertempat di dekat pintu keluar TPS, untuk diberikan tanda khusus berupa tinta yang diteteskan ke salah satu jari Pemilih dan tidak mencelupkan jari Pemilih ke dalam tinta, sebagai bukti bahwa Pemilih yang bersangkutan telah memberikan hak pilihnya.

(4) Pemilih yang telah selesai memberikan suara sebagaimana dimaksud pada ayat (1) segera meninggalkan area TPS dan tidak berkerumun di lingkungan TPS.

Dengan terbitnya PKPU tersebut memberikan rasa aman bagi pemilih dalam menggunakan hak pilihnya sehingga partisipasi politik masyarakat dapat terjaga meskipun pada kenyataan tidak mencapai angka mendekati $90 \%$ penggunaan hak 
pilihnya. Adapun hasil dari pelaksanaa pilkada tersebut dimenangkan oleh pasangan Drs. H. Benyamin Davnie dan H. Pilar Saga Ichsan, ST dengan perolehan suara sebanyak 235.734 suara atau $39,64 \%$ kemudian diikuti oleh pasangan Drs. H. Muhamad, M.Si dan Rahayu Saraswati D. Djojohadikusumo, dengan perolehan suara sebanyak 205.309 suara atau $34,52 \%$ dan ketiga adalah pasangan Dr. Hj. Siti Nurazzizah, SH., M.Hum dan H. Ruhamaben dengan perolehan suara sebanyak 134.682 suara atau $22,65 \%$.

Dengan apa yang dipaparkan sebelumnya dapat dikatakan bahwa antusiasme masyarakat untuk memilih telah mendapatkan jaminan dari pemerintah Kota Tangerang Selatan dan juga KPU Kota Tangerang Selatan sehingga kekhawatiran masalah pandemi Covid-19 dapat dicegah dengan penerapan protokol kesehatan sesuai PKPU. Disamping itu calon-calon walikota Tangerang Selatan menjadi salah satu dorongan masyarakat untuk datang ke TPS untuk melakukan pencoblosan.

\section{DAFTAR PUSTAKA}

Budiardjo, Miriam (2008). Dasar-dasar Ilmu Politik. Jakarta: PT. Gramedia Pustaka Utama

Cucu Sutrisno, Partisipasi Warga Negara Dalam Pilkada, Jurnal Pancasila dan Kewarganegaraan, 2017
Idil Akbar, Pilkada Serentak Dan Geliat Dinamika Politik Dan Pemerintahan Lokal Indonesia, 2017

Mokhammad Samsul Arif, Meningkatkan Angka Partisipasi Sebagai Upaya Menjamin Legitimasi Hasil Pemilihan Kepada Daerah Dan Wakil Kepala Daerahditengah Pandemi Covid-19, 2020

Primandha Sukma Nur Wardhani, Partisipasi Politik Pemilih Pemula dalam Pemilihan Umum, Jurnal Pendidikan Ilmu-Ilmu Sosial, 2018

Sugiyono. (2017). Metode Penelitian Kuantitatif, Kualitatif, dan R\&D. Bandung: Alfabeta, CV

Tim FH Universitas Jambi, Pelaksanaan Pemilihan Kepala Daerah Di Masa Pandemi, 2020

Undang-Undang Republik Indonesia Nomor 6 Tahun 2020 Tentang Penetapan Peraturan Pemerintah Pengganti Undang-Undang Nomor 2 Tahun 2020 Tentang Perubahan Ketiga Atas Undang-Undang Nomor 1 Tahun 2015 Tentang Penetapan Peraturan Pemerintah Pengganti Undang-Undang Nomor 
1 Tahun 2014 Tentang Pemilihan

Gubernur, Bupati, dan Walikota

Menjadi Undang-Undang Menjadi

Undang-Undang

Peraturan Komisi Pemilihan Umum Republik Indonesia Nomor 13 Tahun 2020 Tentang Perubahan

Kedua Atas Peraturan Komisi Pemilihan Umum Nomor 6 Tahun 2020 Tentang Pelaksanaan Pemilihan Gubernur Dan Wakil Gubernur, Bupati Dan Wakil Bupati, Dan/Atau Wali Kota Dan Wakil Wali Kota Serentak Lanjutan Dalam Kondisi Bencana Nonalam Corona Virus Disease 2019 (Covid-19)

Keputusan Komisi Pemilihan Umum Kota Tangerang Selatan Nomor: 470/HK.03.1-Kpt/3674/KPU-

Kot/XII/ 2020 Tentang Penetapan Rekapitulasi Hasil Penghitungan Suara Pemilihan Wali Kota Dan Wakil Wali Kota Tangerang Selatan Tahun 2020

Keputusan Komisi Pemilihan Umum Kota Tangerang Selatan Nomor: 470/HK.03.1-Kpt/3674/KPUKot/XII/ 2020 Tentang Penetapan Jumlah Pemilih Terdaftar Dalam Daftar Pemilih Tetap (DPT) pada
Pemilihan Wali Kota Dan Wakil Wali Kota Tangerang Selatan Tahun 2020

https://megapolitan.kompas.com/read/202 0/09/23/16165031/kpu-tetapkantiga-paslon-dalam-pilkada-tangselmuhamad-sara-azizah diakses pada 13 Januari 2021 pukul 11:04 WIB

https://pilkada2015.kpu.go.id/tangselkota diakses pada 14 Januari 2021 pukul 07:06 WIB

https://kabar24.bisnis.com/read/20201209/ 15/1328375/pilkada-tangsel-2020sebanyak-979109-pemilihmencoblos-hari-ini, diakses pada 22 Februari 2021 pukul 10:30 WIB

https://www.cnnindonesia.com/nasional/2 0200601103545-20508637/lonjakan-drastis-kasuscorona-pada-mei-2020 diakses pada 15 Januari 2021 pukul 21:51 WIB

https://www.inews.id/news/megapolitan/ai rin-klaim-semua-tps-pilkadatangsel-patuhi-protokol-kesehatan diakses pada 21 Feruari 2021 pukul 10:50 WIB 